Indonesian Journal of Nutrition and Dietetics Vol. 6, No. 3, 2018: 113-121
Available online at: http://ejournal.almaata.ac.id/index.php/IJND DOI : http://dx.doi.org/10.21927/ijnd.2018.6(3).113-121

\title{
The increase of blood creatininee levels and the gastric histopathology of rat after feeding of porang (Amorphophallus oncophyllus) flour treated with Strobilantehes crispa
}

\author{
Ernawati ${ }^{1}$, Veriani Aprilia ${ }^{1}$, Retno Pangastuti ${ }^{2}$ \\ ${ }^{1}$ Departement of Nutrition Science, Faculty of Health Sciences, Universitas Alma Ata, Yogyakarta, Indonesia \\ ${ }^{2}$ Prof. Dr. Sardjito Hospitals, Yogyakarta, Indonesia \\ Corresponding author: ernawatiey14@gmail.com
}

\begin{abstract}
ABSTRAK
Latar belakang: Umbi Porang (Amorphophallus oncophyllus) meru[akan umbi asli Indonesia yang mengandung glucomannan. Glukomanan digunakan sebagai bahan tambahan makanan dan suplemen makanan bagi penderita diabetes, tekanan darah tinggi, konstipasi dan penurunan berat badan. Namun, umbi porang mengandung kalsium oksalat yang menyebabkan gatal jika dikonsumsi oleh karena itu kesiapan persiapan yang tepat. Perendaman dari S. crispa in vivo elah terbukti menurunkan kadar kalsium oksalat. Namun, kelebihan konsumsi kalsium oksalat dapat menyebabkan gangguan fungsi ginjal, terutama pada laju flomerasi glomerulus (GFR) dan mempengaruhi kerja ginjal, yaitu penyerapan dan kreatinin fltrasi.

Tujuan: Untuk mengetahui pengaruh porang orang dengan S. crispa (keji beling) terhadap kreatinin darah dan histopatologi lambung tikus (Rattus norvegicus) Wistar pada uji toksisitas akut. Metode: Penelitian ini menggunakan experimental with one test group, without control group. Subjek 20 tikus Wistar betina putih (Rattus norvegicus) dengan berat 110-180 gram, usia 8 - 12 minggu, sehat, dan normal. Kelompok tikus dibagi menjadi Tepung Porang Murni (TPM) dan Tepung Porang dengan ekstrak etanol S. crispa (TPK). Setiap kelompok menggunakan dosis 2000 mg / kg berat badan (BW) dan 5000 mg / kgBB. Data kadar kreatinin dikumpulkan pada 24 dan 72 jam setelah makan juga dikonfirmasikan oleh tikus lambung. Analisis data menggunakan One-Way analysis of ariance (ANOVA).

Hasil: Jenis larutan dan frekuensi perendaman tidak berpengaruh pada kadar kalsium oksalat padatepung porang, sedangkan lama perendaman tidak memberi efek. Kadar kreatinin darah tikus meningkat setelah pemberian pakan Tepung Porang urni (TPM) dan Tepung Porang dengan Ekstraksi Keji Beling (TPK) dengan dosis $5000 \mathrm{mg} / \mathrm{kgBB}$.

Kesimpulan: Pemberian tepung porang dengan perlakuan ekstrak S. crispa aman sampai dosis 5000 mg/ kgBW. Ini terbukti dengan normalitas waktu di tingkat kadar kreatinin.
\end{abstract}

KATA KUNCI: porang umbi, kalsium oksalat, rongga, kreatinin, uji toksisitas akut.

\begin{abstract}
Background: Porang (Amorphophallus oncophyllus) tuber is the original Indonesian tuber containing glucomannan. Glucomannan is utilized as food additives and food supplements for people who have problems with diabetes, high blood pressure, constipation and weight loss. However, it contains calcium oxalate which causes itchy if it is consumed therefore itness appropriate preparation. Soaking of S. crispa in vivo has proven lowering the levels of calcium oxalate. However, the excess consumption of oxalate calcium can cause renal function disorders, especially at the glomerular filtration rate (GFR) and affects the kidneys work, ie absorption and filtration creatinine.

Objectives: The objective of this study is to know the influence of the porang flour with S. crispa (keji beling) on the level of blood creatinine and gastric histopathology of rats (Rattus norvegicus) Wistar on acute toxicity test.

Methods: This research used experimental with one test group, without control group design. The subjects were 20 white female Wistar rats (Rattus norvegicus) with the weight of 110-180 grams, ages of $8-12$ weeks, healthy, and normal. Rats were divided into. Native porang flour (TPM) and porang flour treated
\end{abstract}


with ethanol extracts of S. crispa (TPK) groups. Each of groups used dosage of $2000 \mathrm{mg} / \mathrm{kg}$ body weight (BW) and $5000 \mathrm{mg} / \mathrm{kgBW}$. Data of creatininee levels were collected at $24^{\text {th }}$ and $72^{\text {nd }}$ hours after feeding was also confirmed by gastric rats. The data analysis was used One-Way analysis of variance (ANOVA) . Results: The type of solution and the frequency of soaking had no effect on calcium oxalate levels in the Porang, whereas the length of soaking is not giving an effect. Blood levels of creatinine rats enhanced after feeding of TPM and TPK. At the dosage of $5000 \mathrm{mg} / \mathrm{kgBW}$.

Conclusions: The feeding of porang flour treated with S. crispa was safe until the dosage of $5000 \mathrm{mg} /$ $\mathrm{kgBW}$. It was proven by time normality in creatinine levels.

KEYWORDS: porang tuber, calcium oxalate, cavity, creatinine, acute toxicity test.

\section{INTRODUCTION}

Porang (Amorphophallus oncophyllus) is an original Indonesian tuber plants that are widely cultivated in forest areas the forest of Madiun, East Java (1). The porang is included Araceae family that is also known as iles-iles (1). It is not widely known by the community compared to other types of tubers, so that production is still exclusive and conducted by certain industries only (2).

Glucomannan is a polysaccharide composed of glucose and mannose that has many benefit, such as thickening, gelling and water binding agent. In developed countries, such as Japan, glucomannan used as ingredient of konyaku, nata de coco, shirataki, and supplement food for diabetics, high blood pressure, constipation, weight loss (3). In addition, porang flour has also been studied as a binding agent that affects the physical properties and release of drugs (4).

Despite its high economic value and benefit, porang contains oxalic crystals which when eaten will make the mouth, tongue and throat pierced. Oxalic acid is a dicarboxylic acid having two of $C$ atoms in each carboxylate group. Oxalic acid in plants is stored in two forms, water soluble and water insoluble form. Consumption of oxalic acid in high quantities can decrease the bioavailability of calcium in the body and cause the risk of kidney stone disease. The dissolved oxalate is produced from the oxalate binding to the water- soluble alkali metal, while the insoluble oxalate is produced from the calcium compound with oxalic acid (5). Type of oxalic acid is in needle-shaped tuber and oxalate crystals are not water soluble (6).
Consumption of porang flour had the affect on the digestive organs such as mouth, tongue, esophagus and stomach. The stomach is a mixed endocrine and exocrine organ that digests food and hormones. It also destroy the food and drink consumed, the stomach wall can also absorb certain substances through its walls. This causes the stomach to be susceptible to exposure to toxic substances directly and make it as one of the toxic effect targets (7).

In addition, excessive consumption of oxalic acid over long periods can lead to its accumulation of the kidneys and cause the malfunction of this organ especially at the glomelurus filtration rate (LFG), so that it can affect the kidney work ie absorption and creatininee filtration (8). Creatininee was excreted by kidney through a combination of filtration and excretion with relatively constant concentration in blood plasma. The amount of creatininee that exceeds the normal value indicates decreased of excretion caused by impaired renal function (10). A 2 -fold increase in the amount of creatininee indicates a $50 \%$ reduction in kidney function.

The oxalic acid removal technique from porang has been widely practiced before this studies by cooking or by drying (3). Study of salt concentrations, in soaking treatment, stamp mill, and fractionation ( blower) or grinding by surface response method were also proved to remove the oxalic acid (11-13). In addition, another way that is expected to be used is by immersion of keji beling leaf in vivo which is proven to reduce calcium oxalate levels (14). The studies of toxicity test has proved that $S$. crispa showed no death on animal (15). 
The aims of study were to evaluate the effect of soaking porang with ethanol extract of S. crispa on the level of calcium oxcalate levels. Its influence on the creatininee levels and histopathology levels were also studied.

\section{MATERIALS AND METHODS}

This research was a part of a joint research about porang tuber coordinated by Alma Ata Centerfor Health Life and Food (ACHEAF). This was an experimental research with one group test without control group design. It was conducted in May-July 2017. The subjects were white Wistar rat (Rattus Norvegicus) as many as 20 rats aged 8-12 weeks, weighing 110-180 grams, healthy, and not pregnant. Rats were divided to group of TPM (native porang flour) dose of 2000 and $5000 \mathrm{mg} / \mathrm{kg}$ body weight (BW) and TPK (treated porang flour) dose of 2000 and $5000 \mathrm{mg} / \mathrm{kg} \mathrm{BW}$. TPM was contained $3.27 \%$ of calcium oxalate. The maceration process was performed using $3.2 \%$ of S. crispa extract. Creatininee levels were analyzed from blood rat after feeding of porang at $24^{\text {th }}$ and 72 th hours. In the end of study, gastric hystophatology was also observed.

\section{RESULTS}

\section{Porang flour preparation}

Porang flour was used for feeding after treating with S. crispa extract. The effect of type of solution, duration of soaking and rinsing frequency on the level of porang calcium oxalate were studied.

Table 1 . The effect of solution typeb on ca-oxalate levels

\begin{tabular}{lcc}
\hline \multirow{2}{*}{ Type of Solution } & $\begin{array}{c}\text { Calcium oxalate } \\
\text { level (\%) }\end{array}$ & \multirow{2}{*}{ p-value } \\
\cline { 2 - 2 } & Mean \pm SD & \\
\hline Ethanol & $4.03 \pm 0.09$ & \multirow{2}{*}{0.057} \\
\hline Ethanol + S. crispa & $2.99 \pm 0.04$ & \\
\hline
\end{tabular}

Notes: $p<0.05$ showed significant value with Paired Sample T-test

Table 1, showed that porang treated with ethanol and ethanol extract of $S$. crispa were not significantly different $(p>0.05)$.
Table 2. The effect of period of soaking on caoxalate levels in porang flour

\begin{tabular}{ccc}
\hline $\begin{array}{c}\text { Period of } \\
\text { soaking }\end{array}$ & \begin{tabular}{c} 
Calcium oxalate level (\%) \\
\cline { 2 - 2 }
\end{tabular} & p-value \\
\hline 24 hours & $2.74 \pm 0.08$ & 0.065 \\
\hline 72 hours & $2,99 \pm 0.04$ & \\
\hline
\end{tabular}

Notes : $p<0.05$ showed significant value with Paired Semple T-test

Table 2 showed that there was no significant difference on calcium oxalate content between porang soaking of 24 hours and 72 hours with $p$-value value of $0.065(p>0,05)$. The use of 24 hours period of maceration will be the effective alternative of reducing the calcium oxalate.

Table 3. The effect of rinsing frequency on calcium oxalate levels

\begin{tabular}{lc}
\hline \multirow{2}{*}{ Rinsing Frequency } & \multicolumn{1}{c}{ Calcium Oxalate Level (\%) } \\
\cline { 2 - 2 } & Mean \pm SD \\
\hline 0 times rinse & $5.28 \pm 0.04^{\mathrm{a}}$ \\
\hline 1 times rinse & $3.87 \pm 0.04^{\mathrm{b}}$ \\
\hline 2 times rinse & $2.74 \pm 0.07^{\mathrm{c}}$ \\
\hline
\end{tabular}

Information: Superscript within the same column with the same letters are not significantly different $(p>0.05)$.

Table 3 showed that frequency of rinsing had the impact on the levels of calcium oxalate with $p$ $<0,05$. The decrease range of calcium oxalate after rinsing was between $1.41 \%$ to $2.53 \%$. Then it can be concluded that the most effectiveness processing to decrease the calcium oxalate was 2 times of rinsing.

\section{Creatininee levels of rat blood}

Table 4. Normality test of initial blood creatine content data

\begin{tabular}{cccc}
\hline \multirow{2}{*}{ Treatment Group } & \multicolumn{3}{c}{ Shapiro-Wilk } \\
\cline { 2 - 4 } & Statistic & Df & Sig \\
\hline TPM & 0.90 & 10 & 0.20 \\
TPK & 0.89 & 10 & 0.19 \\
\hline
\end{tabular}

Notes : TPM, native porang flour. TPK, treated porang flour.

Table 4 showed that baseline blood creatininee data were not significant different $(p>0.05)$. The $p$-value of TPM group was 0.202 TPK group was 
Table 5. Blood creatininee levels of rat after $24^{\text {th }}$ hour administration of porang flour

\begin{tabular}{|c|c|c|c|c|}
\hline \multirow{2}{*}{ Treatment group } & \multicolumn{2}{|c|}{ Blood Creatininee (mg / dL) } & \multirow{2}{*}{ P-Value } & \multirow{2}{*}{$\Delta \mathrm{K}$} \\
\hline & Before & After & & \\
\hline TPM 2000 mg/kg BW & $0.66 \pm 0.02^{a}$ & $0.62 \pm 0.03^{a}$ & 0.13 & $-0.04^{a}$ \\
\hline TPM 5000 mg/kg BW & $0.63 \pm 0.05^{\mathrm{a}}$ & $0.77 \pm 0.03^{b}$ & 0.01 & $0.14^{\mathrm{b}}$ \\
\hline TPK 2000 mg/kg BW & $0.63 \pm 0.64^{a}$ & $0.64 \pm 0.02^{a}$ & 0.72 & $0.01^{a}$ \\
\hline TPK 5000 mg/kg BW & $0.65 \pm 0.40^{a}$ & $0.75 \pm 0.03^{b}$ & 0.02 & $0.10^{\mathrm{b}}$ \\
\hline
\end{tabular}

Notes: TPM (native porang flour), TPK (treated porang flour with soaking of $S$. crispa ethanol extract). Superscript within the same column with the same letters are not significantly different $(p>0.05) . \Delta K$ (the difference between the creatininee value of rat blood before and after treatment, analyzed with analysis of variance/Anova).

Table 6. Creatinine level of rat blood before and after 72 hours treatment

\begin{tabular}{|c|c|c|c|c|}
\hline \multirow{2}{*}{ Treatment grouo } & \multicolumn{2}{|c|}{ Blood Creatine Levels (mg / dL) } & \multirow{2}{*}{ P-Value } & \multirow{2}{*}{$\Delta \mathrm{K}$} \\
\hline & Before & After & & \\
\hline TPM 2000 mg / kg BW & $0.66 \pm 0.02{ }^{a}$ & $0.66 \pm 0.03^{a}$ & 0.67 & $0.01^{a}$ \\
\hline TPM 5000 mg / kg BW & $0.63 \pm 0.05^{a}$ & $0.83 \pm 0.02 \mathrm{~b}$ & 0.00 & $0.20^{b}$ \\
\hline TPK $2000 \mathrm{mg} / \mathrm{kg} \mathrm{BW}$ & $0.63 \pm 0.64$ a & $0.66 \pm 0.64$ a & 0.35 & $0.03^{a}$ \\
\hline TPK $5000 \mathrm{mg} / \mathrm{kg} \mathrm{BW}$ & $0.65 \pm 0.40^{a}$ & $0.82 \pm 0.06^{b}$ & 0.01 & $0.18^{b}$ \\
\hline
\end{tabular}

Notes: TPM (native porang flour), TPK (treated porang flour with soaking of $S$. crispa ethanol extract). Superscript within the same column with the same letters are not significantly different $(p>0.05) . \Delta K$ (the difference between the creatininee level of rat blood before and after treatment, analyzed with analysis of variance/Anova).

0.186. It meant't that distribution of data were chategorized normal.

Table 5 showed that after a 24-hour treatment, blood creatininee levels of rat were significantly different in the administration of the same type of porang flour with different doses. While in the different type of porang flour, there was no significant difference after 24 hours treatment within the same dose. Therefore, dosage had the role on the increase od creatininee levels. The decrease in blood creatininee levels of rat in all groups after treatment at 24 hours were ranged from 0.036-0.136 $\mathrm{mg} / \mathrm{dL}$. Blood creatininee levels of normal mice were $0.20-0.80 \mathrm{mg} / \mathrm{dL}$ (16). So it can be concluded that at the observation of the 24th hour treatment of blood creatininee levels were included normal.

Table 6 shows that at the 72 hours of observation, creatininee levels of blood rat increased with the increased of dosage, both in TPM and TPK groups $(p<0.05)$. The decrease of blood creatinine levels after 72 hours of treatment were ranged from 0.01 to $0.20 \mathrm{mg} / \mathrm{dL}$. Blood creatinine levels of normal rat were $0.20-0.80 \mathrm{mg} / \mathrm{dL} 916$ ). It meant that blood

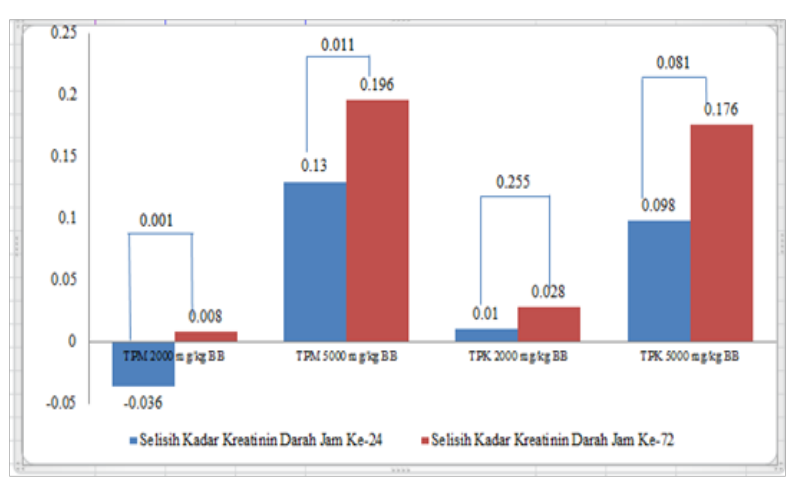

Figure 1. Differences in creatine levels of rats after 24 and 72 hours of treatment

creatinine levels of rat in all treatment groups were normal.

The difference in the creatininee level of rat blood compared between the $24^{\text {th }}$ hour and the $72^{\text {nd }}$ hour after treatment was used to see the changes in blood creatininee levels after the porang administration. The results show that generally, creatininee levels increased at the observation of $24^{\text {th }}$ and $72^{\text {nd }}$ hours. The increased was consistent with the higher of dosage. 

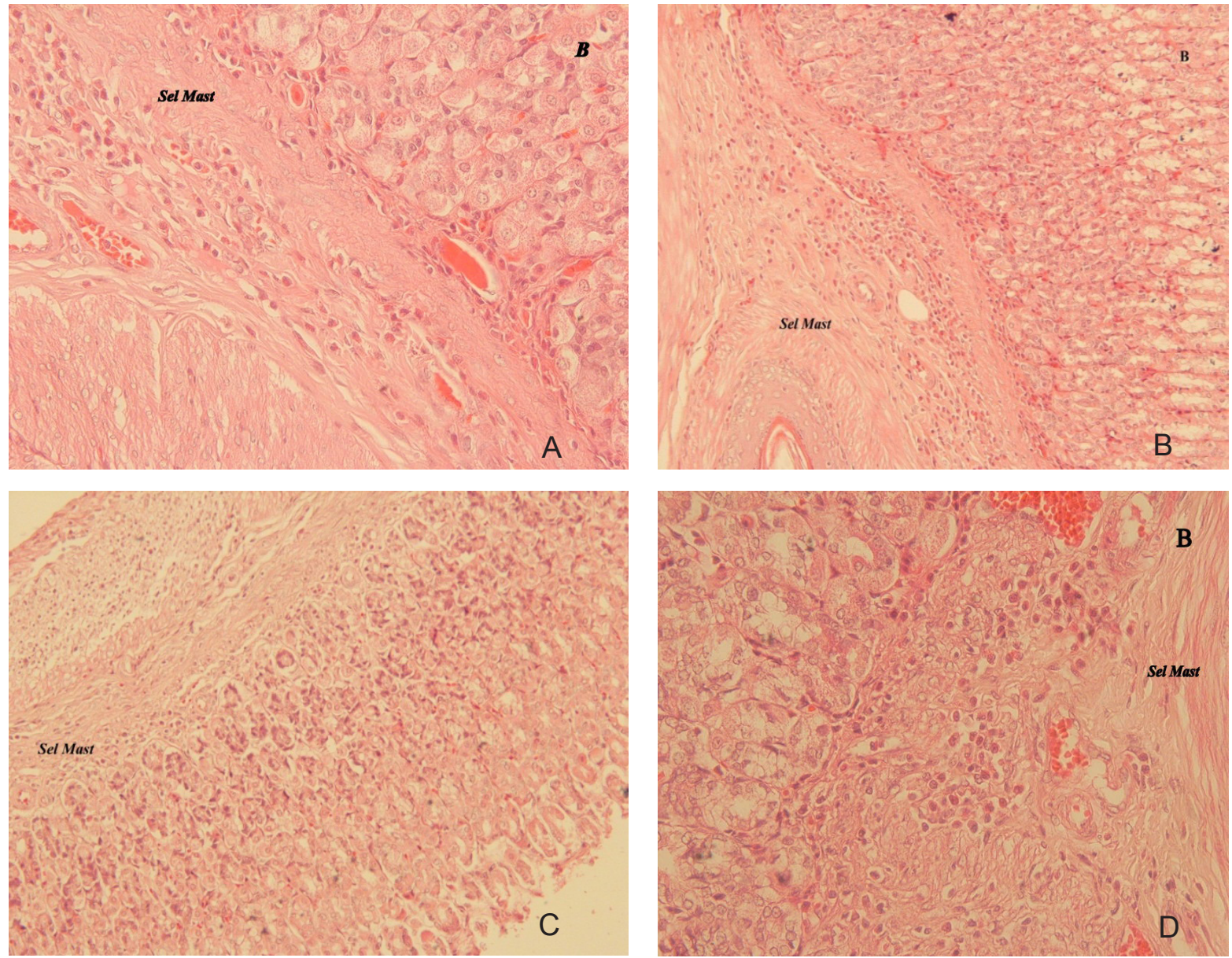

Figure 2. Gastrix histophatology observed at $72^{\text {nd }}$ hour porang administration

Notes: group of TPM 2000 mg/kg BB (inflammation degree +) (A), TPM $5000 \mathrm{mg} / \mathrm{kg} \mathrm{BB}$ (inflammation degree ++) (B), TPK $2000 \mathrm{mg} / \mathrm{kg}$ BB (inflammation degree ++) (C), TPK $5000 \mathrm{mg} / \mathrm{kg} \mathrm{BB}$ (inflammation degree +++)

\section{Gastric Histopathology}

Figure 2 showes that inflammation was found at the lowest degree in the treatment of TPM 2000 $\mathrm{mg} / \mathrm{kg}$ of body weight. The addition of S. crispa increased the degree of inflammation.

\section{DISCUSSION}

\section{Porang flour preparation}

Porang flour was made from porang tuber. Porang has high enough calcium oxalate content, leading to irritation and itching in the throat when eaten (17). Therefore, it is necessary to find the alternative treatment to reduce calcium oxalate levels.

\section{Creatininee levels of rat blood}

Preliminary test was conducted to obtain a starting dose. It used 1 rat for each dose. The doses used were $300 \mathrm{mg} / \mathrm{kg}$ BW because there was no previous research was found using similar test materials and female rats had high sensitivity level compared with male rats (20). The results did not show symptoms of toxicity or death at a dose of 300 $\mathrm{mg} / \mathrm{kg} \mathrm{BW}$, so the starting dose used was $2000 \mathrm{mg} /$ $\mathrm{kg}$ and $5000 \mathrm{mg} / \mathrm{kg} \mathrm{BW}$ with a single dose for 24 .

Kidneys are susceptible organs against the presence of toxic compounds. Creatininee is the final product of cretin metabolism in the muscle. Metabolically, creatinine is an inactive component that diffuses into the plasma and 
is excreted through the urine. Increased blood cretainin levels and the amount of creatininee in the urine can be used to improve glomerolous filtration rate. In this study, creatininee of rat was measured using Jaffe method. This method is quite specific, simple, widely used and can relatively eliminate the intervention of the blood components that can react with reagents on the Jaffe method without modification.

Measurements of blood creatininee levels were performed at the $0^{\text {th }}$ hour before treatment, at 24 hours and 72 hours after treatment. The result of the initial measurement is analyzed by homogeneity of data using Shapiro-wlik test to know the homogeneity of data. The test results revealed that the spread of early blood creatininee data (0 hour) was normal or there was no significant difference between TPM group and TPK group either at the same dose or different dose. It because at the hour 0 , rat had not given the treatment yet.

At the 24 hours creatininee observation results presented in Table $\mathbf{5}$ shows that there was a difference in creatininee levels between the same administration and the different doses $(p<0.005$. At higher doses, blood creatininee levels also increased. It was due to the higher conten of protein and calcium oxalate in the increase of dosage that was leading to higher protein metabolism. In the body, especially the liver, the protein will undergo a deamination process that will produce nitrogen and non nitrogen metobollite. One of them is creatininee which is the final product of nitrogen. And the presence of oxalate will produce free radicals that trigger the occurrence of oxidative stress conditions. This condition is initiated by the release of vasoactive mediators with effect vasoconstriction of blood vessels, in this case the kidney blood vessels and result in a decrease glomerolous filtration rate (FLG) (21).

The average range of blood creatininee levels of rat in all groups after treatment at 24 hours was $0.0060-0.02806 \mathrm{mg} / \mathrm{dL}$. And the creatininee content of rat normal blood was $0.20-0.080 \mathrm{mg} / \mathrm{dL}$ (16). So it can be concluded that the observation of the 24 th hour after treatment of blood creatinine levels in all groups were classified as normal. Therefore, large doses of TPM and TPK have the same effect on the increase of blood cretinine level, so that the soaking treatment of ethanol extract in vermicular calcium oxalate did not affect the increase of blood creatininee level. Some of the factors that can affect blood creatininee levels include sex, famine and muscle tissue size. Increase of blood creatinine levels can also be caused by some of the circumstances such as tissue hypoxia, decreased glomerolous filtration rate, the presence of metabolic disease and toxic chemicals (22).

At the $72^{\text {nd }}$ hour of observations, TPM and TPK administration had significant effect on creatininee levels of rat on the same type of porang with different dosage (Table 6). The mean of blood creatininee level in all groups were ranged between 0.0080-0.2 $\mathrm{mg} / \mathrm{dL}$ that was still within the normal range $(0.20$ $0.80 \mathrm{mg} / \mathrm{dL}$ ). Furthermore, the change in blood creatininee levels at 24 and 72 hours showed no difference except for the treatment of dosage of $2000 \mathrm{mg} / \mathrm{kgBW}$. It may be influenced by rat muscle mass. The rat are in growth mass, so that muscle mass was also slightly increased. The greater the muscle mass, the higher the creatininee level from the metabolism. The decrease in blood creatininee levels of rat was influenced by the dose and duration of administration.

In this study, the dose gave no impact on the given. This was consistent with the study of acute toxicity test using corn hair extract, its effect on Lethal Dose (LD) 50, liver and kidney function was in observed dose of $3.84 ; 7.68 ; 15,36 ; 30.27 \mathrm{~g} /$ $\mathrm{kg}$. It showed that the extract of corn hair water in the highest dose did not result in death and did not affect the liver and kidney function of the rat (23). Other results showed that Kare Bulbs contained prostratin as a potent anti-HIV drug tested in 40 rats of swiss strains given intra-musk snakes $(0.28,0.42$, $0.56 \mathrm{mg} / \mathrm{kg} \mathrm{BW}$ ) in the negative control group and intraperitoneally administered $(0.01,0.015,0.020$ $\mathrm{mg} / \mathrm{kg} \mathrm{BW}$ ) had sub-lethal discharging effects. The percentage of ALT levels in peroral treatment groups (intramusc snake and intraperitoneal) decreased on 14 th day by $1.46-18.76 \%$. While presentation of creatininee levels in the control group and peroral treatment (intramusc snake and intraperitoneal) 
increased on the 14 th day by $20-100 \%$. Statistically it did not show significant difference $(p=0,335)$, but the creatininee level activity had significant difference between control group and treatment $(p=0.00)$. Liver organ damage in the form of picnosis, cariorrexis and cariolysis on organ ren was degenerated on proximal and distal tubulus (24).

In addition, a decrease in mean creatininee levels was possible due to the effect of the use of ethanol extract of $S$. crispa leaf and long exposure of test preparation. S. crispa contains flavonoid compounds, namely natural phenolic compounds that have potential as antioxidants and antiinflammatory (25). Flavonoids exhibit both in vitro and in vivo anti-inflammatory activation. Some of the cellular flavonoid action mechanisms show such activation. This compound may have multiple cellular mechanisms, but its contribution as the most important anti-inflammatory agent was its effect on the activation of the eicosanoid enzyme. Inhibition of eicosanoid enzymes activity will decrease prostaglandin concentration, which will the blood flow decreation to the kidneys (vasoconstriction). It lead to the reduction of inflammatory mediators (26).

\section{Gastric Histopathology}

Histopathologic examination provides information about the target organs of damaged from chemical compounds. It may be observed from the alternation or abnormality in that organs. The stomach is a mixed endocrine-exocrine organ that digest food and hormones. In addition to destroying food and beverages consumed, stomach can also absorb certain substances through the walls. This causes the stomach to be susceptible to exposure to the toxic substances directly and make it one of the targets of the toxic effect (7).

The results of microscopic examination of gastric organs, showed that there were of inflammation and mast cells in the sub mucosa. In TPM and TPK doses of $2000 \mathrm{mg} / \mathrm{kg} \mathrm{BW}$, each showed inflammation of degree one $(+)$ and two $(++)$. However, it showed different results on TPM and TPK administration at dose levels of $5000 \mathrm{mg} /$ $\mathrm{kg} \mathrm{BW}$ of mice with degree of inflammation and mast cells in the sub mucosa were consecutively in degrees of two $(++)$ and three $(+++)$. In the presence of inflammation triggers hemorrhage, that was occurred in gastrointestinal,hem can increase serum creatininee levels without negative effects on kidney which is in the main spotlight (27) ). The inflammatory reactions can increase the number of possible mast cells as a key mechanism to protect the digestive tract from injury. It is occurred in the mucosal immune system that can detect strange things into the mucosa and regulate the inflammatory response that occurs. In the gastrointestinal tract, mast cells biologically activate process, including the regulation of blood flow, the epithelial and endothelial permeability, cans secreted mucosa, gastrointestinal motility (28). The results of another study showed the preparation of combination test of phenolic leaf extract of live and ethanolic extract of Chinese teak leaves dose of $2000 \mathrm{mg} / \mathrm{kg}$ and $5000 \mathrm{~kg} \mathrm{mg} / \mathrm{kg}$ between 14 days in rats wistar strain affects PKPB (Puritan Increase Weight For Day) and showed no symptoms of toxic and therewere also no spectrum toxic effects were significant at the macroscopic observation as well as the results of the histology of the organ that shows the damage a cellular (including the stomach) (28).

The use of porang flour is worried to cause allergies. The cause of the allergy in people maybe come from calcium oxalate content in the porang tuber, leading to itching or heat in the mouth. However, food allergies are usually proteins that do not change during the digestive process. There are four types of calcium oxalate crystals: druse, rafida, prism and sand. Various proteins play a role in the formation of calcium oxalate. The protein was called the matrix protein that includes Asp-rich acidic proteins (many proteins that contain many amino acids asparagin) and Ser-rich glycoproteins (glycoproteins contain many amino serine acids). The protein has a very strong ability to bind calcium. From this description, the subgroup of a lergen on the tuber is the matrix protein in the crystal rather than the calcium oxalate rabbit ( 29 ). Thus the presence of this inflammation from the reaction of the lambung organ to the treatment of TPM and TPK although it does not directly affect the kidney and blood creatininee. 


\section{CONCLUSIONS AND RECOMMENDATION}

The frequency of rinsing affected the decrease of calcium oxalate content in porang, while the type of solution and the period of soaking did not. Rat blood creatininee level slightly increased after TPM and TPK dose $5000 \mathrm{mg} / \mathrm{kg}$ BW. Giving TPM dose of $5000 \mathrm{mg} / \mathrm{kg} \mathrm{BW}$ significantly effected on the increase of blood creatinine level but not on giving of TPK. Gastric histology examination contained inflammatory cells in the gastric sub mucosa on TPM and TPK doses of $5000 \mathrm{mg} / \mathrm{kg}$, but did not directly affect blood levels of creatininee.

The addition of ethanol extract of S. crispa with washing frequency 2 of times each $100 \mathrm{ml}$ can be used to reduce the calcium oxalate content in pure porang so it does not affect kidney function. Consumption of porang flour with the addition of ethanolic extract of $S$. crispa leaves to a dose of $5000 \mathrm{mg} / \mathrm{kg} \mathrm{BW}$ rat or equivalent premises 26 grams/day safe for consumption.

\section{Acknowledgments}

Acknowledgments of the authors was delivered to ACHEAF ( Alma Ata Center for Healthy Life and Food ) for their supports and technicians of PSPG Laboratory (Mr. Yuliyanto). UGM Veterinary Pathology Laboratory (Dr. drh Yuli Purwandari K, MP), which has provided a lot of assistance so that this research can be completed as planned.

\section{REFERENCES}

1. Saleh, Nasir., St. A. Rahayuningsih., Budhi santoso Radjit., Erliana Ginting., Educated Harnowo. IMJM. Plants Porang [Internet] . Center for Food Crops Research and Development. Jakarta: Agency for Agricultural Research and Development; 2015. Available from: http://balitkabi.litbang.pertanian.go.id/ publikasi/petunjuk-teknis/booklet/2217tanamanporang.html.

2. Pramathana A. Characteristics of Porang Flour (Amorphophallus oncophyllus) With Variation Immersion Of Ash And Salt Kitchen In Order To Reduce The Content Of Oxalic Acid. University of Jember;2013.
3. Saleh, Nasir., St. A. Rahayuningsih., Budhi santoso Radjit., Erliana Ginting., Educated Harnowo. IMJM. Vi, BAB Amorphophallus, Suweg. Jakarta: Agency for Agricultural Research and Development;2015.

4. Business P, With I, Olap T. Proceeding of the 7th SNST 2016 Faculty of Engineering Wahid Hasyim University Semarang 7. 2016; 7-12.

5. Ardhian D and SI. Content of Porang Oxalate (Amorphophallus muelleri Blume) Result of Planting with Treatment of $P$ and K Fertilizer 2013: 53-6.

6. Afifah, E., Mudita Oktorina Nugraheni. S. Opportunity of lles-lles Cultivation (Amorphophallus spp.) As An Interrupted Plant In Rubber Plantations. War Perkaretan. 2014; 33 (1): 35-46.

7. Simanjuntak PP. Acute Toxicity Test Combination of Noni Extract (Morinda c itrifolia L.) With Mangosteen Skin Extract (Garcinia m angostana L) On Female Wistar Mouse. Universitas Gadjah Mada Yogyakarta; 2015.

8. Prayitno. H. Effect of Avocado N-Avocado Fraction Against Ureum and Creatininee In Mice. Bogor Agricultural Institute; 2010.

9. Rahmania Dwi Hartati. 2. Effect of Combination of Ethanol Extract of Starfruit Fruit (Averrhoa blimbi

L.) and Tara Dara Leaf (Catharanthus r oseus

G.) Long Term Against Kidney Function (Pre Clinical Study). Muhammadiyah Surakarta university; 2015.

10. Luh Gede Merry Cintya Lakshmi N, Ketut Anom Dada I, Made Damriyasa I, Faculty of Veterinary Medicine $\mathrm{M}$, Udayana $\mathrm{U}$, Veterinary Surgery L, et al. Bioactivity Tapakdara Leaf Extract (Catharanthus roseus) to Creatininee and Blood Ureum Level of White Rat (Rattus norvegicus). Bul Vet Udayana. 2014; 6 (2).

11. Wijayanti FD. Decrease in Oxalate Levels On Pork Flour g (Amorphophallus oncophyllus) Study Concentrations Kitchen Salt And Old Immersion . Brawijaya Malang; 2009.

12. Aqoba G. Decrease in Calcium Oxalate Levels in Porang Flour (morphophallus Onchophyllus) mechanically using Stam Mill and fractionation 
(Blower) (Old Testing Assessment) . Universitas Brawijaya Malang; 2009.

13. Faridah A. Mechanical With Response Surface Method. J Tek Ind. 2012; Volume 13, (August 2012): 158-66.

14. Dharma, S. Aria, M. Syukri E. Effect of Ethanol Extract of Belong Leaves (Strobilanthes Crispa (L) Blume) to Calcium Oxalate Solubility As Kidney Stone Component In Male Rat Urine Urine . 2014; 1 (4): 34-7.

15. Hasanah U. Acute Toxicity Test of Porang Flour (Amorphophallus Onchophyllus) with and without Maseration Extracts of Gingival Shell And Kidney Histopathology In Wistar Rat (Rattus norvegicus). University of Alma Ata Yogyakarta; 2017.

16. Mitruka BM. Clinical Biochemical and Hematological Reference Values in Normal Experimental Animals and Normal Humans. In: Second Edi. United States of America: Masson Publishing USA, Inc.; 1981.

17. Koswara S. Umbian Processing Technology - Umbian Part 2: Porang Bulb Processing.

18. Swintari NW, Khaerati K. Combination Activity of Soursop Leaf Extract (Annona Muricata L.) and Pegagan Leaves (Centella Asiatica L. Urb) on Solubility. 2017; 3 (March): 34-42.

19. Widjanarko SB, Sutrisno A, Faridah A . Effect of Hydrogen Peroxide on Physicochemical Properties of Common Konjac (Amorphophallus oncophyllus) Flour by ... 2015; (September 2012).

20. Head of P, Supervisor B, Dan O, Indonesia R, Cara $T$, Sarana $P$, et al. Indonesian drug and food republic. Jakarta; 2012 p. 1-28.

21. N N. Effect of Ethanol Extract of Avocado Leaf Pe. IPB; 2010.

22. Amir N, Suprayitno E, Nursyam H. Effect Of Sipermetrin On Jambal Bread Against Ureum And Creatininee Mice Wistar Rat
(Rattus $n$ orvegicus) Effect Of Cypermethrin Bread Too On And Creatininee Levels Of Wistar Rats (Rattus $n$ orvegicus). 2015; 2 (April): 28393.

23. Nuridayanti EFT. Acute Toxicity Test Acute Toxicity Test Corn Corn Water Extract (Zea Mays L). Depok; 2011.

24. Princess E. 5. ALT and Creatininee Mice (Mus Musculus Linnaeus, 1758) Females In Acute Toxicity Ethanolic Extracts of Stem Skin Kareumbi (Homalanthus Populneus (Geisel.) Pax) . Universitas Gadjah Mada Yogyakarta; 2015.

25. ientarsih ietje. Serum Ureum and Creatininee Serum in White Rats given Ethyl Acetate Leaf Fraction Avocado . A Vet. 2012; Volume: 13 (Issue: 1): Pages: 57-63.

26. A, Suharyadi . SAM. The Effects of Soursop Leaf Ethanol Extract on Renal Histopathological Analysis of DMBA Induced. Juke Unila Fac Med Lampung Univ [Internet]. 2015; Available from: juke.kedokteran.unila.ac.id/index.php/majority/ article/viewFile/500/501\%0A.

27. Funchs, CT. and Hewitt P. Biomarkers For DrugsInduced Renal Demage And Nephrotoxicity-An Overview For Apllied Toxicology. AAPS J. 2011; 13 (4): 616-31.

28. Mutmainah. Effectiveness of Gastroprotective Turmeric Infusa (Curcuma domestica L.), Cardamom (Ammomum compactum S.) and Sembung Leaf (Blumea balsamifera DC.) In the Gastric Model Tukak [Internet] Model. Gadjah Mada University Yogyakart; 2013. Available from: http://etd.repository. ugm.ac.id/index.php? mod=penelitian detail\&sub=Detail Research\&act = view\&typ=html\&buku_id=62862

29. Permana, Sofyan., Dian Siswanto., Aris Soewondo S. Allergenity Test Various Variants of Porang Bulb (Amorphophallus oncophyllus Hook). Poor; 2010 . 